\title{
Motor Difficulties in Elementary School and Its Relationship with Extracurricular Sport Activities
}

\author{
Miriam Palomo Nieto \\ Universidad Politécnica de Madrid, Madrid, Spain \\ Email: miriam.palomo@upm.es
}

How to cite this paper: Nieto, M. P. (2021). Motor Difficulties in Elementary School and Its Relationship with Extracurricular Sport Activities. Advances in Physical Education, 11, 312-319.

https://doi.org/10.4236/ape.2021.112026

Received: February 2, 2021

Accepted: May 28, 2021

Published: May 31, 2021

Copyright ( 2021 by author(s) and Scientific Research Publishing Inc. This work is licensed under the Creative Commons Attribution International License (CC BY 4.0).

http://creativecommons.org/licenses/by/4.0/

\section{(c) (i) Open Access}

\begin{abstract}
Motor difficulties have prevalence between $5 \%$ and $18 \%$ in children aged between 4 and 11 years old depending on the measuring instruments. These children do not enjoy with the PE lessons neither with other extracurricular sport activities, so that they do not receive the numerous physical health benefits from this practice. However, the aim of the study was to determine how children performing other sport activities could reach higher levels of motor competence. 138 school children were observed, and the MABC-2 checklist was completed per each. At the same time, a socio-sport questionnaire was filled. Results showed how those children older and performing more extracurricular sport activities had a better motor performance in the way of the previous research showing how the practice could help to improve in the motor competence regardless of the original motor level.
\end{abstract}

\section{Keywords}

Clumsiness, Developmental Coordination Disorder (DCD), MABC-2,

Dyspraxia

\section{Background}

Motor clumsiness is referred in the literature as dyspraxia (Maeland, 1992), perceptual-motor difficulties (Fonseca, 1996), motor coordination problems (Rusell, 1988), minimal brain dysfunction (Sudgen \& Keogh, 1990), minimal cerebral palsy (Ruiz, 2004), movement problems, motor infantilism (Cratty, 1979), congenital clumsiness (Henderson, 1993), or motor retardation (Wall, Reid, \& Patton, 1990).

Based on these definitions, boys and girls with movement difficulties are 
classified as "clumsy children". They present movement problems not only in Physical Education classes or extracurricular activities related to physical activity or sport, but also in their daily life, showing, lack of balance, difficulty catching moving objects or awkward movements when performing personal hygiene tasks as brushing the teeth or combing the hair.

When thinking about the daily life of a primary school student with coordination difficulties, Physical Education classes are spaces where they have to carry out some of the tasks that are more difficult for them, such as dressing and undressing, catching the ball, balancing themselves, which can generate a situation with lots of pressure by not performing this task too quickly or too good as their classmates. And also, once this task has been carried out, they must leave the gym and participate in activities with the rest of their classmates, a situation again that can lead to tension or anxiety due to the difficulty of carrying out the different tasks proposed.

It is hard to find common characteristics to all schoolchildren with motor skills difficulties, since this group has been considered as a heterogenous group. Some of the children have a lack in terms of balance tasks, others feel terrible when performing catching or aiming tasks, some other children feel disoriented, get bored or are mocked by the rest of their classmates. So that, they decide to give up the activity or not join sport extracurricular activities.

Following with the difficulties, what school-children do should be measured because it is necessary to know their competence. To diagnose and evaluate the different levels of motor competence in primary education, it has been necessary to use a set of tests and batteries that help to detect those schoolchildren at risk of having developmental coordination problems or already have real difficulties to move with competence.

Apart of this, Hernández (1995) states that students with motor clumsiness can suffer other associated non-motor disorders such as, extreme changes of character; inadequate reproduction of geometric shapes, confusion with figure and background, dyslexia, symbolization, and lastly attention problems, difficulties in assimilating, storing and retrieving information, being the comorbility in the last years, an increasing studied topic.

Viciana and Zabala (2004) point out that the two aspects of sport, instructive and educational, should be worked by both teachers in the Physical Education field during school hours and by sports coaches or monitors in the schedule of extracurricular activities. Coaches should focus on teaching sports content and educating young athletes to accept and regulate their behaviors coping with adversity, control press, victories or defeats. Although it is important that these aspects are taught to every child, those with motor difficulties show more rejection to the sport extraculrricular activities, since no motivation for them exists.

So that, the aim of the study was to observe the presence of motor coordination problems in a sample of school boys and girls during physical education classes, as well as to determine the degree of incidence with extracurricular sports activity of schoolchildren. 


\section{Method}

\subsection{Participants}

138 school children (74 male and 64 female) with a range of age between 7 and 12 years old (mean 9.1 and SD 1.7) participated in the study. All the children were from a private school in Madrid and they were divided into three age groups ( 7 - 8 years old 45 children; 9 - 10 years old 46 children; 11 - 12 years old 47 children).

\subsection{Instruments}

To carry out the research, two instruments were used. To check the level of motor competence of the students it was used the Movement ABC2 Battery Observation Sheet. To know about the extracurricular sports practice, it was used a questionnaire carried out ad hoc for this research. Both instruments are detailed below.

\subsubsection{Motor Competence}

To evaluate the motor competence of the participants in the study, the Sheet Movement ABC2 Battery Observation Sheet (Henderson \& Sugden, 1992) was used. This observation sheet is based on the observation of tasks claimed in the classroom

To score each of the activities, a Likert-type scale from 0 to 4 was used, being 0 very good, 1 good, 2 regular and 3 very difficult. A score of 4 implies not observed. The sum of all the scores for each of the sections generates a total score. This total score reflects the level of motor competence of the student, being divided by colored stripes, green indicating a normal motor level, orange a risk of having motor difficulties and red the presence of motor difficulties in that student.

\subsubsection{Extracurricular Practice}

To determine the level of extracurricular practice, a socio-sports questionnaire was filled by the schoolchildren. The questionnaire was made up by 9 items about each one's sports and extracurricular activity routines. The questions sought to obtain detailed information on the extracurricular sports routines. Likewise, the questionnaire also collected information about with whom they practiced sports.

\subsection{Procedure}

In order to carry out this research, the head of the school was contacted to explain the aim of the study. Once the approval was given by the head of the school but also by the education teachers, it was selected the groups (2nd, 4th and 6th of Primary Education). All the students received a letter explaining the meaning of the study as well as its anonymous nature that had to be signed by theirs parents or legal guardians, accepting participating in the study.

Once the consents were received 24 group sessions (4 sessions per group) 
were needed to observe the children. In these sessions, the physical education teachers carry out different activities (already planned to check the motor competence) with the students while the research group observed each movement of the students. After these sessions, 2 more individualized sessions were carried out per group in which each student could be observed in a more personal way performing different activities from the observation sheet of the Movement ABC2 Battery.

After obtaining all the motor competence data, a last session was held with the boys and girls in the classroom where they were given the socio-sports questionnaire.

\section{Results}

In order to determine the existence of significant differences in each of the sections (Section A and Section B), as well as the global value of the behavioral observation list of the M-ABC2 based on different variables, a one-way ANOVA was carried out, where Section A, Section B and the global value of the behavioral observation list were taken as the dependent variable, and sex, class, grade, age as independent variable. The results obtained show significant differences in Section A depending on the sex (Table 1), being the boys who obtain the highest scores not only in that section but also in the global value of motor competence level (Table 2). Likewise, significant differences were found in Section A and in the Level of Motor Competence depending on the class, the course and the age (Tables 3-5).

Table 1. ANOVA depending on the sex.

\begin{tabular}{ccc}
\hline Dependent variable & F & Sig. \\
\hline Section A & 4.80 & 0.030 \\
Section B & 0.000 & 0.990 \\
Global Value & 1.86 & 0.175 \\
\hline
\end{tabular}

Table 2. Standard deviation depending on the sex.

\begin{tabular}{ccccc}
\hline & & $\mathrm{N}$ & Mean & Standard deviation \\
\hline \multirow{2}{*}{ Section A } & Chico & 74 & 3.77 & 4.57 \\
& Chica & 64 & 2.28 & 3.15 \\
& Total & 138 & 3.08 & 4.03 \\
& Chico & 74 & 5.35 & 4.21 \\
\hline Section B & Chica & 64 & 5.36 & 3.33 \\
& Total & 138 & 5.36 & 3.81 \\
\hline \multirow{2}{*}{ Global Value } & Chico & 74 & 1.74 & 0.795 \\
& Chica & 64 & 1.56 & 0.753 \\
& Total & 138 & 1.66 & 0.778 \\
\hline
\end{tabular}


Table 3. ANOVA depending on the class.

\begin{tabular}{ccc}
\hline Dependent variable & F. & Sig. \\
\hline Section A & 3.25 & 0.008 \\
Section B & 2.01 & 0.081 \\
Global Value & 6.65 & 0.000 \\
\hline
\end{tabular}

Table 4. ANOVA depending on the school-year.

\begin{tabular}{ccc}
\hline Dependent variable & F. & Sig. \\
\hline Section A & 8.16 & 0.000 \\
Section B & 2.55 & 0.081 \\
Global Value & 16.05 & 0.000 \\
\hline
\end{tabular}

Table 5. ANOVA depending on the age.

\begin{tabular}{ccc}
\hline Dependent variable & F. & Sig. \\
\hline Section A & 3.80 & 0.003 \\
Section B & 1.40 & 0.227 \\
Global Value & 7.03 & 0.000 \\
\hline
\end{tabular}

Since the results of the ANOVA showed significant differences it was carried out post hoc tests (Bonferoni). These tests determined significant differences between 2nd grade in group A and 6th grade in group A in Section A, being the 6 th grade class the one obtaining lower results. In the same way, the 2 nd grade class in group B obtained significant differences with the same class in 6th grade group $\mathrm{A}$, as in the previous case, the 6th grade class obtained the lowest results in that Section A.

In the global value section, it was founded significant differences between the 2nd grade group A class and the two 6th grade classes, obtaining higher results for this grade (6th grade).

Continuing in the global value it could be seen that the difference of the 2nd class of primary group B had significant differences with the 4th group A, and the two classes of 6 th, being the 2 nd group $B$ class the one that obtained the lowest results.

As in the previous section, Bonferroni post hoc tests were carried out, these tests determined significant differences both in section $\mathrm{A}$ and in the global value between 2 nd grade and 4 th grade and 2 nd grade and 6th grade, with 2 nd grade being those that obtained higher values.

In this section, appeared also significant differences in section A between the age groups of 7 and 9 years and 7 and 11 years, with higher values for 7 -year-old schoolchildren. Regarding the global value, there were differences to be noted between the 7 and 9-year-old, 7 and 10-year-old and 7 and 11-year-old schoolchildren, the lowest results being obtained by the younger schoolchildren. 
Subsequently, the same analyzes were carried out in order to determine the possible significant differences in each of the sections, as well as in the global value based on the questions of the socio-sports questionnaire. One-way ANOVA analyses showed significant differences in Section B in the questions: Do you like to play sports? $(p<0.007)$; Are you signed up for any after-school activity during the week? $(p<0.000)$; Do you compete in any sports league? $(p<$ $0.000)$ And do you practice sports during the weekend? $(p<0.004)$. Likewise, in this last question, significant differences were found in Section B $(p<0.004)$ and also in the global value of the behavioral observation sheet $(p<0.012)$. In the last question of the questionnaire, no significant differences were found.

\section{Discussion}

The main purpose of this study was to investigate the importance of the educational and professional experience of teachers when carrying out observation tasks of possible motor problems in students, as well as to verify the relationship between the practice of physical activity extracurricular with motor coordination problems in the different stages of primary education.

Motor problems in physical education class

After having carried out the research, it has been observed that within the physical education classroom, there is a percentage of $18.8 \%$ of students with motor competence problems, as Cratty (1982) cites, who states that between 10 and 20 percent of schoolchildren develop some type of motor clumsiness. This percetage also has been seed in studies by Palomo, Psotta, Agricola, Abdollahipour, \& Valtr (2015) or Ruiz, Rioja, Graupera, Palomo, \& Garcíal (2015).

Regarding the investigated group, the vast majority of the boys and girls are enrolled in some extracurricular activity, so most of them have a correct command of the basic skills present in the physical education class such as jumping, running and throwing, as well as other capacities also worked in all sports such as coordination and balance.

It was observed that the boys and girls who were not enrolled in any extracurricular activity had the worst results in the tests in Section B. This might be because the tests in that section are tests more related to sports activity than to the daily physical activity and a lack of sports activity could be related with a lower motor competence (Ruiz et al., 2005).

\section{Different stages of primary education}

Significant difference was observed between the first grades observed (2nd grade of primary school) and the upper grades such as 4th and 6th grade of primary school. Regarding motor competence, the 6th grade group had better results than the 2nd grade primary course in Section A. However, it is the 2nd grade group the one who had better results in the global value. This could be because the main reasons for starting physical-sporting practice in young people are: for fun, to spend time and to do physical exercise and the main cause is to be with friends, in the first years schoolchildren go to these activities are more 
out of obligation or as an extra hour before returning home, and it is in the upper grades where the student has greater freedom to decide whether he wants to attend activities or not.

Given this difference, it can be said by applying the above that in the lower grades the schoolchildren attend sports initiation activities, often playing games, and as they get older they improve their technique and in turn improve motor skills.

It can be seen that it is the higher courses that have obtained better results in more "technical" tests than the lower courses that have obtained better results in the tests that were of coordination of movements of the day to day and more global.

Influence of extracurricular activities on the motor development of boys and girls

In the observed group $90 \%$ of schoolchildren practice some type of extracurricular sporting activity, like soccer, rhythmic gymnastics, swimming or basketball being the most practiced. Given the circumstances of the school where the study was carried out and the area of the community where the school is located, children have an infinite number of places where they could practice extra-curricular sports, which benefits this high percentage of participation in this.

It is observed that schoolchildren who are not enrolled in any extracurricular activity have worst results in section B, since this section, as mentioned above, is a bit more technical when it comes to taking the tests, following many authors (Lopes, Rodrigues, Maia, \& Malina, 2010; Lubans, Morgan, Cliff, Barnett, \& Okely, 2010; van Beurden et al., 2003).

Even the schoolchildren who did not participate in any sports league have also obtained worse results in this Section B.

Influence of the observed group

As mentioned above, the group to be observed presents a very heterogeneous level of motor skills since there is an age difference of 6 years between the smallest schoolchild and the oldest schoolchild of the participants in the study.

With a large number of boys and girls (138) it has been easy to make a realistic comparison of the results obtained.

\section{Conflicts of Interest}

The author declares no conflicts of interest regarding the publication of this paper.

\section{References}

Cratty, B. (1979). Motricidad y Psiquismo en Educación y Deporte. España: Miñón.

Cratty, B. (1982). Desarrollo perceptual y motor en los niños. Barcelona: Paidós.

Fonseca da, V. (1996) Estudio y Génesis de la Psicomotricidad. Barcelona: INDE Publicaciones.

Henderson, S. (1993). Motor Development and Minor Handicap. In A. F. Kalverboer, B. 
Hopkins, \& R. Geuze (Ed.), Motor Development in Early and Later Childhood: Longitudinal Approaches (pp. 286-306). Cambridge: Cambridge University Press. https://doi.org/10.1017/CBO9780511663284.020

Henderson, S., \& Sugden, D. (1992). Movement Assessment Battery for Children Manual. Sidcup, Kent: The Psychological Corporation.

Hernández, F. J. (1995). Torpeza motriz. Un modelo para la adaptación curricular. Barcelona: Flor del Viento ediciones S.A.

Lopes, V., Rodrigues, L., Maia, J. A. R., \& Malina, R. M. (2010). Motor Coordination as Predictor of Physical Activity in Childhood. Scandinavian Journal of Medicine and Science in Sports, 21, 663-669. https://doi.org/10.1111/j.1600-0838.2009.01027.x

Lubans, D. R., Morgan, P. J., Cliff, D. P., Barnett, L. M., \& Okely, A. D. (2010). Fundamental Movement Skills in Children and Adolescents: Review of Associated Health Benefits. Sports Medicine, 40, 1019-1035. https://doi.org/10.2165/11536850-000000000-00000

Maeland, A. F. (1992) Handwriting and Perceptual-Motor Skills in Clumsy, Dysgraphic, and "Normal" Children. Perceptual and Motor Skills, 75, 1207-1217. https://doi.org/10.2466\%2Fpms.1992.75.3f.1207

Ministerio de Educación y Ciencia, Hernández, J., \& Velazquez, R. (1996) La actividad física y deportiva extraescolar en los centros educativos. Madrid: Artegraf.

Palomo, M., Psotta, R., Agricola, A., Abdollahipour, R., \& Valtr, L. (2015). The Effects of Various Visual Conditions on the Gait Cycle in Children with Different Level of Motor Coordination-A Pilot Study. RICYDE. Revista Internacional de Ciencias del Deporte, 42, 387-399. https://doi.org/10.5232/ricyde2015.04207

Ruiz, L. M. (2004). Moverse con dificultad en la escuela. Sevilla: Wanceulen editorial deportiva, S.L.

Ruiz, L. M., Mata, E., \& Jiménez, F. (2005). Percepción Visual y Problemas Evolutivos de Coordinación Motriz en la Edad Escolar. Archivos de medicina del deporte, 22, 213-224.

Ruiz, L. M., Rioja, N., Graupera, J. L., Palomo, M., \& Garcíal, V. (2015). GRAMI-2: Desarrollo de un Test Para Evaluar la Coordinación Motriz Global en la Educación Primaria. Revista Iberoamericana de Psicología del Ejercicio y el Deporte, 10, 103-111.

Rusell, J. P. (1988). Graded Activities for Children with Motor Difficulties. Cambridge: Cambridge University Press.

Sudgen, D., \& Keogh, J. (1990). Problems in Movement Skill Development. Columbia, SC: University of South California Press.

Van Beurden, E., Barnett, L. M., Zask, A., Dietrich, U. C., Brooks, L. O., \& Beard, J. (2003). Can We Skill and Activate Children through Primary School Physical Education Lessons? "Move It Groove It". A Collaborative Health Promotion Intervention. Preventive Medicine, 36, 493-501. https://doi.org/10.1016/S0091-7435(02)00044-0

Viciana, J., \& Zabala, M. (2004). Un estudio descriptivo sobre cómo planifican los profesores de Educación Física. In M. A. González, A. Sánchez y Gómez, \& J. Actas del (Eds.), International Congress of AIESEP 2002. Preparación profesional y necesidades sociales. A Coruña (pp. 732-739). A Coruña.

Wall, A. T., Reid, G., \& Patton, J. (1990). The Syndrome of Physical Awkward. Advances in Psychology, 74, 283-316. https://doi.org/10.1016/S0166-4115(08)61185-1 